\title{
Mechanical shrub control on flatwoods range in south
} Florida

\author{
GEORGE W. TANNER, JOHN M. WOOD, ROBERT S. KALMBACHER, AND FRANK G. MARTIN
}

\begin{abstract}
Relative plant abundance, canopy cover, and aerial biomass of shrubs on a poor condition, flatwoods range in south Florlda were measured before, 1 , and 3 yr after a single pass of a roller chopper or web plow when solls were dry (May 1981) and when soils were saturated (September 1981). Aerial biomass of herbaceous species was measured at the post-treatment sample dates. Abundance of saw-palmetto (Serenoa repens (Bartr.) Small) plants, the dominant shrub, was reduced $70 \%$ by web plowing compared to $25 \%$ by roller chopping. Reductions of saw-palmetto canopy cover and aerial biomass also were greater on web-plowed than on roller-chopped plots. Runner oak (Quercus minima (Sarg.) Small) was the only other shrub which had more than $5 \%$ canopy cover before treatment. Both types of mechanical treatments controlled runner oak by approximately $50 \%$. However, responses of runner oak abundance, canopy cover, and aerial biomass were not significantly different between roller chop and web plow treatments.
\end{abstract}

Key Words: roller chopping, web plowing, saw-palmetto, runner oak

Flatwoods range provides much of the forage for cow-calf enterprises in south Florida (Kirk et al. 1974). Frequent winter burning (2- to 3-yr interval) traditionally is used to remove accumulations of senescent forages and to stimulate nutritious regrowth. Winter fires, however, only temporarily reduce shrub competition. Saw-palmetto (Serenoa repens Bartr.) Small) can regain $80 \%$ of pre-burn canopy cover in 1 growing season (Hilmon 1968).

Past range improvement practices attempted to control sawpalmetto and increase production of bluestems (Andropogon spp.) and other grasses (Yarlett 1965). Roller drum choppers, usually pulled in tandem at off-set angles, have been the most commonly used mechanical method for saw-palmetto control. The web plow was originally developed in south Florida for conversion of rangeland to cropland and has been used for saw-palmetto control. The web plow has a flat, V-shaped sharpened, steel blade that is mounted on a road grader. The blade plows at a depth of 10 to 15 $\mathrm{cm}$ and causes very little surface soil disturbance.

Saw-palmetto control with double passes of a roller chopper varied from $45 \%$ reduction in canopy cover at $3 \mathrm{yr}$ post-treatment (Kalmbacher and Martin 1984) to $94 \% 2$ yr post-treatment (Moore 1974). Lewis (1972) reported $42 \%$ reduction in saw-palmetto canopy cover 6 months after web plowing. However, saw-palmetto control on web-plowed rangeland appears to be much greater than Lewis' estimate.

The objective of this study was to compare shrub control and forage responses following web plowing and roller chopping. The treatments were installed at the extremes of soil moisture, i.e., during a drought and during saturated (flooded) conditions.

\section{Study Area}

This study was conducted on the Desoto County Land and Cattle Company, $30 \mathrm{~km}$ southeast of Arcadia, Desoto County, Florida. Climate within this area is characterized by hot, humid summers and mild winters. Freezing temperatures are sporadic

\footnotetext{
Authors are associate professor and biologist, Department of Wildlife and Range Sciences; professor, Department of Agronomy; and professor, Department of Statistics, University of Florida, Gainesville 3261 1. Fla. Agric. Exp. Sta. Journal Series No. 6693.
}

Manuscript accepted 24 November 1987. and associated with rapidly passing cold fronts. Annual rainfall (30-yr average) recorded in Arcadia is $141 \mathrm{~cm}$, most of which is received between June and September.

Soils of the Myakka series (sandy, siliceous, hyperthermic Aeric Haplaquod) dominated the south Florida flatwoods study site. These sandy soils developed from strongly acid marine sediments and are poorly drained due to the development of spodic horizons at depths of 30 to $50 \mathrm{~cm}$. Sheet flow over the nearly flat terrain occurs during rainy seasons, while in dry seasons the water table may recede to depths of more than $1 \mathrm{~m}$.

The study site was treeless, but scattered slash pines (Pinus elliottii Engelm.) were in the vicinity. Saw-palmetto was the dominant shrub. Pineland threeawn (Aristida stricta Michx.) was the dominant grass. Although several bluestem species were present, the site was in poor condition.

The study area had been burned on an approximate 2-yr cycle and grazed continuously for many years. A deferred-rotation grazing system providing 4 to 6 months of rest each year was begun in 1980.

\section{Methods}

Twenty 1.8-ha plots were established on the study site in March 1981. Four plots were roller chopped and 4 were web plowed during a dry spring ( 1 May 1981) and each treatment was applied to 4 plots during the following wet summer (3 September 1981). Four untreated plots served ac checks. Treatments were assigned in a completely random design. Chopping was a 1-way treatment with tandem-drum, Marden ${ }^{R}$ M-10 chopper filled with water and pulled at 8.0 to $10.0 \mathrm{~km} / \mathrm{hr}$ with a 104.4 kilowatt rubber-tired tractor. Each of the tandem drums was a $3.05 \mathrm{~m}$ in length and weighed approximately $5.7 \mathrm{mT}$.

Pretreatment estimates of shrub biomass, canopy cover, and relative abundance (number of plants/linear distance) were made 20 to 27 March 1981 and 31 August to 2 September 1981. Four randomly located, $40-\mathrm{m}$ line transects were permanently marked in each plot. Canopy cover and number of intercepted plants of each shrub species were recorded for each line transect. Total aerial biomass of each shrub species was estimated by harvesting from 10 , $0.25-\mathrm{m}^{2}$ quadrats along each transect. Green weights were recorded in the field. A subset of shrub biomass samples was oven-dried at $60^{\circ} \mathrm{C}$ for $48 \mathrm{hr}$, for converting field weights to dry weights. Posttreatment estimates were taken in the same manner 13 and 14 December 1982 and 9 and 10 October and 19 November 1984.

The entire study site was burned in February 1984 to remove any accumulation of standing dead vegetation in all treated and untreated plots and to promote regrowth. This would highlight the potential difference between mechanically treated and untreated plots. The burn was not intended to affect shrubs. Hilmon (1968), Moore et al. (1974), and Abrahamson (1984) documented that the major shrub species characteristic of Florida's flatwoods range replace their pre-burn canopy cover within the growing season following a winter fire.

The experimental design consisted of a completely random allocation of chop and web machine treatments when the soil condition was very dry (May 1981) and again randomly allocated when the soil condition was saturated (September 1981). Data from wet and dry experiments were pooled and analyzed as a series of 
experiments following the Cochran and Cox (1957) methodology for analyzing data from experiments repeated in time or space. Analyses of covariance were used to estimate shrub abundance, canopy cover, and aerial standing crop. Pretreatment estimates were used as the covariates. Pair-wise t-tests, using least square means, were made between the untreated plots and the 4 machine type-soil condition treatment combinations.

\section{Results}

Soils at the study site were extremely dry at time of treatment in May 1981 . Only $1.8 \mathrm{~cm}$ of rain was recorded in Arcadia, Florida (ca $48 \mathrm{~km}$ to the NW), during March and April. Almost $35 \mathrm{~cm}$ of rain were received in late August, resulting in approximately 5 to $10 \mathrm{~cm}$ of standing water on the site at the time of treatment in September 1981.

Although 14 shrub species were encountered in the study plots, only saw-palmetto and runner oak (Quercus minima Sarg.) Small) had pretreatment canopy cover estimates greater than 5\%. The other 12 shrub species were combined into an "other shrub" category which consisted of ground huckleberry (Gaylussacia dumosa (Andr.) Torr \& Gray), dwarf wax myrtle (Myrica cerifera L. var pumila Michx.), Chapman's oak (Quercus chapmanii Sarg.), American beautyberry (Calicarpa americana L.), queen's delight (Stillingia sylvatica L.), gallberry (Ilex glabra (L.) Gray), fetterbush (Lyonia lucida (Lam.) D. Don), staggerbush (L. ferruginea (Walter) Nutt.), St. John's-wort (Hypericum brachyphylum (Spach) Steud.), St. Peter's-wort (Ascyrum stans Michx.), ground blueberry (Vaccinium myrsinites Lam.), and paw-paw (Asimina spp.).

\section{Saw-palmetto Responses}

Estimated saw-palmetto plant abundance was lower in both roller chopped and web plowed plots at 1 and 3 yr following treatment (Table 1). Also, web plowed plots had lower sawpalmetto plant abundance (ca 50\% lower) than roller chopped plots at both sampling dates. These results represent an overall reduction of saw-palmetto plant numbers by about $25 \%$ and $68 \% 3$ yr following chopping and webbing, respectively, compared to pretreatment conditions. Abundance of saw-palmetto in the chopdry treatment combination was not significantly different from the untreated plots, at 1 and $3 \mathrm{yr}$ after treatment, whereas, abundance estimates in the other 3 treatment combinations were different from the untreated plots.

Canopy cover estimates of saw-palmetto in chopped and webbed plots were significantly lower compared to the untreated plots in both 1 and 3 yr after treatment (Table 1). Also, average saw-palmetto canopy cover estimates in the webbed treatment were significantly lower (by about one half) than in chopped plots in both years. In comparison to pretreatment conditions, chopping and webbing reduced saw-palmetto by about $50 \%$ and $72 \%$, respectively, at $3 \mathrm{yr}$ post-treatment. Saw-palmetto canopy cover in the chop-dry treatment combination was not significantly different from canopy cover in the untreated plots at both post-treatment sampling dates.

Estimated aerial biomass of saw-palmetto following both mechanical treatments was significantly lower than the untreated plots 1 and $3 \mathrm{yr}$ after treatment (Table 1). Saw-palmetto biomass in chopped and webbed plots was similar. Saw-palmetto biomass in the chop-dry treatment combination was not significantly different from estimates in the untreated plots 1 and $3 \mathrm{yr}$ after treatment.

\section{Runner Oak Responses}

Runner oak was the second most abundant shrub on the study site, averaging about 35 plants $/ 40 \mathrm{~m}$ in 1981 (Table 2). Both mechanical treatments resulted in lower abundance estimates than in untreated plots 1 and 3 yr following treatment. However, runner oak abundance was similar in roller-chopped and web-plowed areas. Runner oak abundance in all 4 machine-soil condition treatment combinations was significantly lower than in untreated plots.

Runner oak canopy cover estimates were significantly lower following both mechanical treatments than in untreated plots 1 and 3 yr after treatment (Table 2). Chopping and webbing caused similar reductions in canopy cover of runner oak. Canopy cover of runner oak in chop-wet and web-dry treatment combinations was significantly lower than in the untreated plots in 1982 and 1984.

Runner oak biomass in the untreated plots also were significantly greater than in both mechanical treatment plots 1 and $3 \mathrm{yr}$ post-treatment (Table 2). As with saw-palmetto biomass, runner oak biomass was similar in chopped and webbed plots. Runner oak biomass was significantly lower following the chop-wet treatment combination than in the untreated plots in 1982 and again in 1984 along with the web-dry treatment response.

\section{"Other Shrub" Responses}

Abundance of the "other shrub" category was significantly lower on untreated plots than in both mechanical treatments 1 yr after treatment (Table 3). St. Peter's-wort was stimulated by machine treatment and accounted for the increased abundance in the "other shrub" category. However, the prescribed fire in February 1984 reduced St. Peter's wort abundance below pretreatment conditions on all study plots when measured 3 yr after mechanical treatment. Plots chopped and webbed under wet soil conditions had signifi-

Table 1. Average shrub abundance, canopy cover and aerial biomass of saw-palmetto before mechanical treatment (1981) and 1 and 3 yr after roller chopping and web plowing in a dry April and a wet September, Desoto, Co., Florida.

\begin{tabular}{|c|c|c|c|c|c|c|c|c|}
\hline & \multicolumn{4}{|c|}{ Machine type' } & \multicolumn{4}{|c|}{ Machine-soil condition combination ${ }^{2}$} \\
\hline & Year & Untreated & Chop & Web & Chop-Dry & Chop-Wet & Web-Dry & Web-Wet \\
\hline Relative (abundance) & $\begin{array}{l}81 \\
82 \\
84\end{array}$ & $\begin{array}{l}51.4 \mathrm{a} \\
62.8 \mathrm{a} \\
59.8 \mathrm{a}\end{array}$ & $\begin{array}{l}50.7 \mathrm{a} \\
37.6 \mathrm{~b} \\
39.4 \mathrm{~b}\end{array}$ & $\begin{array}{l}\text { - (no p } \\
52.8 \mathrm{a} \\
15.9 \mathrm{c} \\
18.1 \mathrm{c}\end{array}$ & $\begin{array}{r}\mathrm{s} / 40 \mathrm{~m}) \\
41.6 \\
49.9 \\
49.6\end{array}$ & $\begin{array}{l}59.7 \\
25.3^{*} \\
29.9^{*}\end{array}$ & $\begin{array}{l}65.2 \\
17.0^{*} \\
20.1^{*}\end{array}$ & $\begin{array}{l}45.4 \\
15.3^{*} \\
16.6^{*}\end{array}$ \\
\hline Canopy cover & $\begin{array}{l}81 \\
82 \\
84\end{array}$ & $\begin{array}{l}34.7 a \\
44.4 a \\
36.4 a\end{array}$ & $\begin{array}{l}30.6 \mathrm{a} \\
16.4 \mathrm{~b} \\
15.3 \mathrm{~b}\end{array}$ & $\begin{array}{r}30.6 a \\
7.4 c \\
8.6 c\end{array}$ & $\begin{array}{l}20.2 \\
23.6 \\
20.0\end{array}$ & $\begin{array}{c}40.9 \\
9.3^{*} \\
10.6^{*}\end{array}$ & $\begin{array}{r}26.4 \\
9.1^{*} \\
10.6^{*}\end{array}$ & $\begin{array}{c}33.0 \\
6.3^{*} \\
7.4^{*}\end{array}$ \\
\hline Aerial biomass & $\begin{array}{l}81 \\
82 \\
84\end{array}$ & $\begin{array}{l}1785.6 \mathrm{a} \\
1592.0 \mathrm{a} \\
1177.5 \mathrm{a}\end{array}$ & $\begin{array}{r}1856.1 \mathrm{a} \\
552.0 \mathrm{~b} \\
387.4 \mathrm{~b}\end{array}$ & $\begin{array}{r}1887.1 \mathrm{a} \\
187.6 \mathrm{~b} \\
215.7 \mathrm{~b}\end{array}$ & $\begin{array}{r}1846.0 \\
890.9 \\
597.8\end{array}$ & $\begin{array}{c}1866.3 \\
213.1^{*} \\
176.9^{*}\end{array}$ & $\begin{array}{c}2192.6 \\
106.7^{\star} \\
268.7^{\star}\end{array}$ & $\begin{array}{c}1703.7 \\
176.1^{*} \\
183.8^{*}\end{array}$ \\
\hline
\end{tabular}

Mean values among machine treatments within each species-year combination followed by the same letter are not significantly different at the 0.05 level according to analysis of variance $F$-tests.

${ }^{2}$ An asterisk $(*)$ denotes significant differences $(P<0.05)$ from the check value in each species-year combination excluding 1981 according to pair-wise $t$-tests. 
Table 2. Average thrub abundance, canopy cover and aerial blomase of runner oak before mechanical treatment (1981) and 1 and 3 yr after roller chopping and web plowing in a dry April and a wet September, Denoto Co., Florida.

\begin{tabular}{|c|c|c|c|c|c|c|c|c|}
\hline & \multicolumn{4}{|c|}{ Machine type! } & \multicolumn{4}{|c|}{ Machine-soil condition combination ${ }^{2}$} \\
\hline & Year & Untreated & Chop & Web & Chop-Dry & Chop-Wet & Web-Dry & Web-Wet \\
\hline & & & & - no & $8 / 40 \mathrm{~m})$ & & & \\
\hline Relative (abundance) & $\begin{array}{l}81 \\
82 \\
84\end{array}$ & $\begin{array}{l}30.6 \mathrm{a} \\
26.9 \mathrm{a} \\
37.9 \mathrm{a}\end{array}$ & $\begin{array}{l}41.2 \mathrm{a} \\
12.3 \mathrm{~b} \\
18.9 \mathrm{~b}\end{array}$ & $\begin{array}{l}33.7 \mathrm{a} \\
15.3 \mathrm{~b} \\
21.1 \mathrm{~b}\end{array}$ & $\begin{array}{l}7.0 \\
0.8^{*} \\
0.9^{*}\end{array}$ & $\begin{array}{l}6.2 \\
1.1^{*} \\
3.1^{*}\end{array}$ & $\begin{array}{c}11.1 \\
0.9^{*} \\
2.1^{*}\end{array}$ & $\begin{array}{l}2.0 \\
2.1^{*} \\
1.4^{*}\end{array}$ \\
\hline Canopy cover & $\begin{array}{l}81 \\
82 \\
84\end{array}$ & $\begin{array}{c}6.4 \mathrm{a} \\
9.4 \mathrm{a} \\
11.8 \mathrm{a}\end{array}$ & $\begin{array}{l}7.5 a \\
3.2 b \\
4.9 b\end{array}$ & $\begin{array}{l}6.5 a \\
3.8 b \\
5.4 b\end{array}$ & $\begin{array}{l}4.5 \\
4.3 \\
5.4\end{array}$ & $\begin{array}{c}10.6 \\
2.2^{*} \\
4.4^{*}\end{array}$ & $\begin{array}{l}3.5 \\
2.1^{*} \\
2.3^{*}\end{array}$ & $\begin{array}{l}8.3 \\
4.9 \\
7.2\end{array}$ \\
\hline Aerial biomass & $\begin{array}{l}81 \\
82 \\
84\end{array}$ & $\begin{array}{l}239.5 \mathrm{a} \\
312.1 \mathrm{a} \\
458.2 \mathrm{a}\end{array}$ & $\begin{array}{l}428.7 a \\
110.6 b \\
189.6 b\end{array}$ & $\begin{array}{l}381.3 \mathrm{a} \\
159.0 \mathrm{~b} \\
188.4 \mathrm{~b}\end{array}$ & $\begin{array}{l}256.1 \\
151.9 \\
231.1\end{array}$ & $\begin{array}{c}601.4 \\
69.3^{*} \\
148.0^{*}\end{array}$ & $\begin{array}{c}181.7 \\
122.9 \\
69.4^{*}\end{array}$ & $\begin{array}{l}501.1 \\
180.6 \\
259.6\end{array}$ \\
\hline
\end{tabular}

'Mean values among machine treatments within each species-year combination followed by the same letter are not significantly different at the 0.05 level according to analysis of variance F-tests.

${ }^{2}$ An asterisk $\left({ }^{*}\right)$ denotes significant differences $(R<0.05)$ from the check value in each species-year combination excluding 1981 according to pair-wise $t$-tests.

Table 3. Average shrub abundance, canopy cover and aceial blomase of "other shrubs" before mechanical treatment (1981) and 1 and 3 yr after roller chopplag and web plowing in a dry April and a wet September, Desoto, Co., Florida.

\begin{tabular}{|c|c|c|c|c|c|c|c|c|}
\hline & \multicolumn{4}{|c|}{ Machine typel } & \multicolumn{4}{|c|}{ Machine-soil condition combination ${ }^{2}$} \\
\hline & Year & Untreated & Chop & Web & Chop-Dry & Chop-Wet & Web-Dry & Web-Wet \\
\hline Relative (abundance) & $\begin{array}{l}81 \\
82 \\
84\end{array}$ & $\begin{array}{l}12.2 \mathrm{a} \\
12.1 \mathrm{a} \\
10.3 \mathrm{a}\end{array}$ & $\begin{array}{c}13.8 \mathrm{a} \\
24.7 \mathrm{~b} \\
8.2 \mathrm{a}\end{array}$ & $\begin{array}{r}\text { (no } \\
15.3 \mathrm{a} \\
20.1 \mathrm{~b} \\
4.7 \mathrm{~b}\end{array}$ & $\begin{array}{r}s / 40 \mathrm{~m}) \\
1.3 \\
10.9 \\
7.0\end{array}$ & $\begin{array}{c}1.5 \\
38.5^{\circ} \\
9.3\end{array}$ & $\begin{array}{c}1.9 \\
11.3 \\
4.1\end{array}$ & $\begin{array}{c}1.3 \\
25.4^{*} \\
5.1^{*}\end{array}$ \\
\hline Canopy cover & $\begin{array}{l}81 \\
82 \\
84\end{array}$ & $\begin{array}{l}2.8 \mathrm{a} \\
3.0 \mathrm{a} \\
2.3 \mathrm{a}\end{array}$ & $\begin{array}{l}2.5 \mathrm{a} \\
4.6 \mathrm{a} \\
1.5 \mathrm{a}\end{array}$ & $\begin{array}{l}2.5 \mathrm{a} \\
3.8 \mathrm{a} \\
1.1 \mathrm{a}\end{array}$ & $\begin{array}{l}1.8 \\
1.9 \\
1.4\end{array}$ & $\begin{array}{l}3.2 \\
7.3^{*} \\
1.6\end{array}$ & $\begin{array}{l}2.5 \\
1.6 \\
0.8^{*}\end{array}$ & $\begin{array}{l}2.5 \\
5.1 \\
1.2\end{array}$ \\
\hline Aerial biomass & $\begin{array}{l}81 \\
82 \\
84\end{array}$ & $\begin{array}{l}141.8 \mathrm{a} \\
240.8 \mathrm{a} \\
121.7 \mathrm{a}\end{array}$ & $\begin{array}{r}108.5 \mathrm{a} \\
130.1 \mathrm{a} \\
74.2 \mathrm{a}\end{array}$ & $\begin{array}{r}140.6 \mathrm{a} \\
130.3 \mathrm{a} \\
63.3 \mathrm{a}\end{array}$ & $\begin{array}{l}97.2 \\
98.9 \\
88.9\end{array}$ & $\begin{array}{r}119.7 \\
161.3 \\
59.5\end{array}$ & $\begin{array}{r}148.5 \\
61.5 \\
42.4\end{array}$ & $\begin{array}{r}135.9 \\
171.5 \\
75.8\end{array}$ \\
\hline
\end{tabular}

'Mean values among machine treatments within each species-year combination followed by the same letter are not significantly different at the 0.05 level according to analysis of variance F-tests.

${ }^{2}$ An asterisk $\left(^{*}\right)$ denotes significant differences $(\mathcal{}<0.05)$ from the check value in each species-year combination excluding 1981 acconding to pair-wise -tests.

cantly higher "other shrub" abundance than untreated plots in 1982. However, in 1984, "other shrub" abundance in webbed plots under both dry and wet soil conditions was significantly lower than in untreated plots.

Canopy cover estimates of the "other shrubs" category following both mechanical treatments were not significantly different from those in untreated plots 1 and $3 \mathrm{yr}$ after treatment (Table 3). An approximate 30 -fold increase in St. Peter's-wort canopy cover (from 0.1 to $3.2 \%$ ) during the year immediately following mechanical treatment masked reductions in canopy cover that occurred for all other combined species but ground blueberry. Canopy cover of the "other shrubs" category was significantly higher following the chop-wet treatment than in untreated plots in 1982, but was significantly lower following the web-dry treatment in 1984. The prescribed fire in February 1984 reduced the influence of St. Peter'swort.

Aerial biomass of the "other shrubs" category was not significantly reduced by either mechanical treatment (Table 3). Biomass of St. Peter's-wort increased sharply in the year following treatment ( 3 to 5 fold) then declined by 1984 in a similar manner to abundance and canopy cover of this species due to the fire.

\section{Discussion}

Both roller chopping and web plowing can reduce relative abun- dance, canopy cover, and aerial biomass of saw-palmetto for at least $3 \mathrm{yr}$. Also, the data indicate that web plowing was more effective in controlling saw-palmetto than roller chopping. Chopping provided less control than webbing due to the apparent ineffectiveness of the single pass roller chopper treatment when soils were dry.

Visual observations of the roller chopping process indicated that blade penetration into the soil was not as great at the dry May treatment date as at the wet September date. The apparent inability of roller chopping to control saw-palmetto during drought conditions with a single pass can not be ascertained from this study but warrants further research. Past studies using double chopping treatments ( 2 passes over same area) indicated best saw-palmetto kill during dry soil conditions (Hilmon et al. 1963, Lewis 1970 , Moore 1974). The first pass of the roller chopper crushes the plant, and the second pass usually severs above-ground prostrate stems and lifts the plants out of the ground. Results of this study suggest that a single pass of a roller chopper during saturated soil conditions may give adequate control of saw-palmetto. Further study is needed to test this possibility since a single chop treatment would be much less costly than the traditional double chop treatment.

Web plowing apparently was effective in controlling sawpalmetto in both dry and wet soil moisture conditions. The web 
plow is mechanically inserted below ground; therefore, dry sandy soil conditions do not impede the root-cutting ability of the machine. Web plowing, however, requires more specialized machinery (road grader) than roller chopping.

Many of the other woody plant species (e.g., gallberry, fetterbush, staggerbush, and runner oak) characteristic of flatwoods range sprout readily from roots and are not effectively controlled by these mechanical treatments. Runner oak, the woody species second in dominance on this study site, is a low-growing $(<0.5 \mathrm{~m}$ in height) shrub that is an important mast-producing wildlife food source (Harlow and Jones 1965, Moore 1974). Although initially reduced in plant abundance, canopy cover, and aerial biomass the first year following treatment, this species appeared to be making a recovery by the third year post-treatment. Likewise, ground blueberry, an important deer browse species (Harlow et al. 1975) included in the "other shrubs" group, recovered by 3 yr posttreatment.

Overall responses of the "other shrubs" category were dominated by the St. Peter's-wort individual response. Plant abundance, canopy cover, and aerial biomass of St. Peter's-wort increased sharply following mechanical treatment but decreased to below treatment levels by the third year. This single-stemmed, non-rooting-sprouting species was susceptible to the prescribed fire.

\section{Literature Cited}

Abrahamson, W.G. 1984. Species responses to fire on the Florida Lake Wales Ridge. Amer. J. Bot. 71:35-43.
Cochran, W.G., and G.M. Cox. 1957. Experimental designs, 2nd edition. John Wiley and Co., New York.

Harlow, R.F., and F.K. Jones. 1965. The white-tailed deer in Florida. Fla. Game and Fresh Water Fish Comm. Tech. Bull. 9.

Harlow, R.F., J.B. Whelan, H.S. Crawford, and J.E. Skeen. 1975. Deer foods during years of oak most abundance and scarcity. J. Wildl. Manage. 39:330-336.

Hilmon, J.B., C.E. Lewis, and J.E. Bethune. 1963. Highlights of recent results of range research in southern Florida. Soc. Amer. Forest. Proc. 1962:73-76.

Hilmon, J.B. 1968. Autecology of saw-palmetto (Serenoa repens (Bartri.) Small). Ph.D. diss., Duke University.

Kalmbacher, R.S., and F.G. Martin. 1984. Chopping and tebuthiuron effects on saw palmetto. Soil and Crop Sci. Soc. Fla. Proc. 43:86-89.

Kirk, W.G., E.M. Hodges, F.M. Peacock, L.L. Yarlett, and F.G. Martin. 1974. Production of cow-calf herds: effect of burning native range and supplemental feeding. J. Range Manage. 27:136-139.

Lewis, C.E. 1970. Responses to chopping and rock phosphate on south Florida ranges. J. Range Manage. 23:276-282.

Lewis, C.E. 1972. Chopping and webbing control saw-palmetto in south Florida. USDA, Forest Serv. Southeast Forest Exp. Sta. Res. Note SE-177.

Moore, W.H. 1974. Some effects of chopping saw-palmetto pineland threeawn range in southern Florida. J. Range Manage. 27:101-104.

Yarlett, L.L. 1965. Control of saw-palmetto and recovery of native grasses. J. Range Manage. 18:344-345.

Yarlett, L.L., and R.D. Rowh. 1970. Creeping bluestem (Andropogon stolonifer (Nash) Hitch). J. Range Manage. 23:117-122.

\section{June 15, 1988, Deadline for 1989 Annual Meetlng Paper Titles}

Titles are now being solicited for papers to be presented at the 42nd Annual Meeting of the Society for Range Management, February 19-23, 1989, in Billings, Montana. Complete the following form and submit to Dr. J.E. Taylor, SRM Program Chairman, Department of Animal and Range Sciences, Montana State University, Bozeman, MT 59717, Phone (406)9945575. Deadline for abstracts is August 1, 1988. See the inside front cover of April Rangelands for additional information.

Title

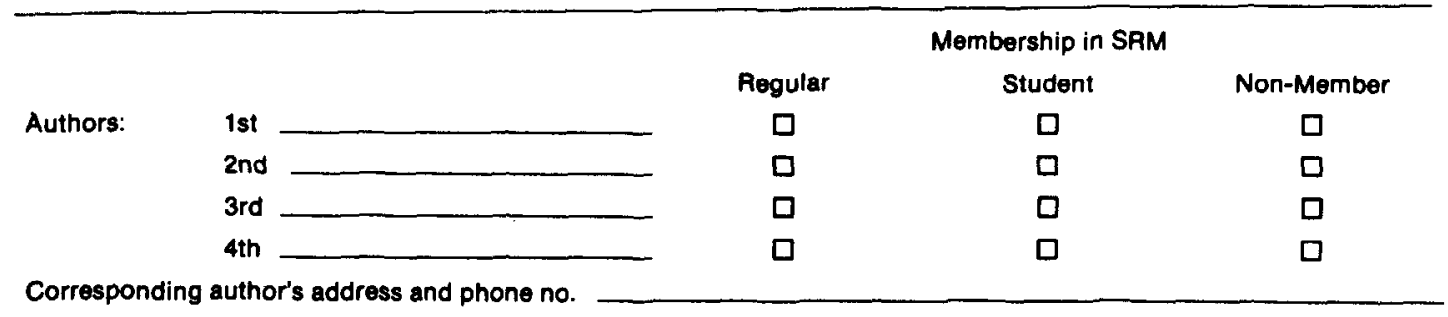

Indicate presenting author with asterisk

I. Presentation preference $\square$ Poster

II. Subject Matter (Check preference) Ecology

ㅁ. Autecology

$\square$ Synecology

[ Taxonomy

Piant-Soil Relationships

$\square$ Competition

$\square$ Succession

$\square$ Rangeland Reference Areas

D Economice Ecophystology

$\square$ Germination

$\square$ Photosynthesis

$\square$ Water Relations

Carbohydrate Trends

$\square$ Rooting Behavior

$\square$ Allelopathy

$\square$ Nutrient Cycling

$\square$ Plant Response to

Defoliation

\section{Grazing Management}

$\square$ Animal Behavior

$\square$ Soil Effects

$\square$ Systems

$\square$ Plant Response

$\square$ Animal Response

Improvements \& Land Reclamation

$\square$ Burning

$\square$ Fertilization

C Chemical

$\square$ Mechanical

$\square$ Soeding

$\square$ Strategies

Diological

$\square$ Irrigation

$\square$ Plant Selection
Traditional

Inventory Evaluation

$\square$ Methods

[ Measurements

[ Techniques

D Remote Sensing

Animal Nutrition

a Animal Diets

[] Diet Quality

$\square$ Wildlife

[ Supplementation

Solla/Hydrology

0 Erosion

D Hydrology

[ Nutrient Cycling

[] Plant-Soil Relationships

[] Watershed Manegement

Grad Student Competition

Wildilfe

$\square$ Wildlife Habitat Relationships

$\square$ Impact of Domestic Livestock on Wildlife Species

D Predator-Prey Relationships

$\square$ Livestock/Wildlife Integration

$\square$ Rancher's Forum Rangeland Poate

$\square$ Insects

$\square$ Weeds

$\square$ Other 